\title{
Gas-chromatographic lipid profiles in identification of currently known slowly growing environmental mycobacteria
}

\author{
Pirjo Torkko, ${ }^{1,2}$ Marja-Leena Katila ${ }^{2}$ and Merja Kontro ${ }^{1} \dagger$ \\ ${ }^{1}$ Laboratory of Environmental Microbiology, National Public Health Institute, PO Box 95, FIN-70701 \\ Kuopio, Finland \\ ${ }^{2}$ Department of Clinical Microbiology, Kuopio University Hospital, PO Box 1777, FIN-70211 Kuopio,
Finland
}

Pirjo Torkko

pirjo.torkko@ktl.fi

\begin{abstract}
Cellular fatty acid analysis by GLC is widely used in the species identification of mycobacteria. Combining mycolic acid cleavage products with shorter cellular fatty acids increases the informative value of the analysis. A key has been created to aid in the identification of all currently known slowly growing environmental species. In this scheme, the species are classified into six categories, each characterized by a combination of fatty markers shared by those species. Within each category, individual species may be distinguished by the presence or absence of specific marker substances, such as methyl-branched fatty acids or secondary alcohols. This study also describes earlier unpublished GLC profiles of 14 rare, slowly growing, environmental mycobacteria, Mycobacterium asiaticum, Mycobacterium botniense, Mycobacterium branderi, Mycobacterium conspicuum, Mycobacterium cookii, Mycobacterium doricum, Mycobacterium heckeshornense, Mycobacterium heidelbergense, Mycobacterium hiberniae, Mycobacterium kubicae, Mycobacterium lentiflavum, Mycobacterium scrofulaceum, Mycobacterium triplex and Mycobacterium tusciae. Though no single identification technique alone, even sequencing of an entire single gene such as 16S rRNA, can identify all mycobacterial species accurately, GLC has proven to be both reliable and reproducible in the identification of slowly growing mycobacteria. In cases of earlier unknown species, it generates useful information that allows their further classification and may lead to the description of novel species.
\end{abstract}

Received 1 November 2002

Accepted 18 December 2002

\section{INTRODUCTION}

Environmental mycobacteria are an emerging problem as causative agents of diseases, especially among immunocompromised hosts. Many mycobacterial species previously regarded as non-pathogenic to man are today classified as inducers of mycobacterioses, this occurring predominantly in AIDS patients (Carbonara et al., 2000; Luque et al., 1998; Mayo et al., 1998). The precise identification of species is of great importance for appropriate patient management. Environmental microbial flora, also rich in mycobacteria, represent a reservoir of previously unknown species (Torkko et al., 2002). In the 1980s, the genus Mycobacterium amounted to about 40 documented species. Today, the number has increased to over 90, and novel species, both saprophytic and potential pathogens, are continually being

†Present address: Department of Ecological and Environmental Sciences, University of Helsinki, Niemenkatu 73, FIN-15140 Lahti, Finland.

Abbreviation: MACP, mycolic acid cleavage product. introduced (Tortoli et al., 2001b; Willumsen et al., 2001; Wilson et al., 2001; Torkko et al., 2002). The taxonomic classification of a new bacterial species is based on the genetic and biochemical characteristics of a group of identical or highly similar unclassifiable isolates. The chemical analysis of their lipid composition is regarded as essential for categorization of a new species (Vincent Lévy-Frébault \& Portaels, 1992). Both fatty acid analysis by GLC and mycolic acid analysis by HPLC are commonly applied techniques (Luquin et al., 1991; Butler \& Guthertz, 2001).

In the routine identification of isolates recovered from both clinical and environmental sources, GLC analysis has proven to be highly applicable for the identification of the increasing number of validly described mycobacterial species. It has also been found to be a helpful tool in classifying isolates that do not meet the identification criteria of currently accepted species (Brander et al., 1992; Koukila-Kähkölä et al., 1995; Torkko et al., 2000, 2001, 2002). If the GLC analysis is extended to cover both mycolic acid cleavage products 
(MACPs) and cellular fatty acids, the method is increasingly reliable for species identification (Chou et al., 1998; Müller et al., 1998; Torkko et al., 1998).

In the present work, the main focus was on GLC identification of recently described or rare slowly growing species and their differentiation from the well-established species. The identification scheme devised relied on visual assessment of the fatty acid profile. Three rapid biochemical tests, which were found to be useful for final confirmation of certain species, were incorporated into the scheme.

\section{METHODS}

Bacterial strains. Strains used in this study were mostly type strains, originating from several type culture collections (Table 1). They were stored in Middlebrook $7 \mathrm{H} 9$ broth (Difco) at $-80{ }^{\circ} \mathrm{C}$ and subcultured for GLC analyses on Middlebrook 7H11 agar supplemented with OADC enrichment (Difco) at $36^{\circ} \mathrm{C}$. Haemin and mycobactin $J$ were respectively added for growth of Mycobacterium haemophilum and Mycobacterium genavense. Mycobacterium cookii, M. haemophilum and Mycobacterium marinum were incubated at $30{ }^{\circ} \mathrm{C}$ and Mycobacterium botniense, Mycobacterium heckeshornense and Mycobacterium xenopi at $42{ }^{\circ} \mathrm{C}$. For this study, cells were harvested after $3-5$ weeks incubation to ensure the production of all fatty acids.

GLC method. In the direct transesterification procedure, the bound fatty acids were cleaved from cells by mild acid hydrolysis and derivatized to the corresponding methyl esters to convert them into volatile compounds suitable for GLC. The method was described previously in detail (Jantzen et al., 1989; Torkko et al., 1998) and was used with minor modifications. In practice, one loopful of bacteria was harvested into acidic methanol and incubated for $16 \mathrm{~h}$ at $85^{\circ} \mathrm{C}$. Fatty acid methyl esters were extracted with $n$-hexane. The analyses were performed with a Perkin-Elmer AutoSystem gas-liquid chromatograph, equipped with a fused-silica capillary column coated with methylpolysiloxane (NB-30, $25 \mathrm{~m} \times 0.32 \mathrm{~mm} \times 0.25 \mu \mathrm{m}$; HNU-Nordion). TurboChrom Workstation software (version 6.1.2.0.1; Perkin-Elmer) was used in the operation of sampling, analysis and integration of the chromatographic data. The carrier gas was helium at a pressure of $8 \mathrm{lb}$ in $^{-2}(55 \cdot 2 \mathrm{kPa})$. The injector and flame-ionization detector temperatures were $325^{\circ} \mathrm{C}$ and the oven temperature was programmed from $125^{\circ} \mathrm{C}$ (hold for $1 \mathrm{~min}$ ) to $280^{\circ} \mathrm{C}$, rising by $10{ }^{\circ} \mathrm{C} \mathrm{min}{ }^{-1}$ and holding at $280^{\circ} \mathrm{C}$ for $7.5 \mathrm{~min}$. Sample size was $1 \mu \mathrm{l}$ in the splitless injection; the split was opened after $1 \mathrm{~min}$. Individual fatty acids were identified by comparing their retention times with those of a standard mixture of straight-chain saturated fatty acid methyl esters between $\mathrm{C}_{14}$ and $\mathrm{C}_{26}$. Identification of methyl-branched fatty acids and alcohols was based on the appropriate retention time relationships observed in previously published profiles of known mycobacterial species. The identity of fatty marker substances was additionally determined by mass spectrometry (MS) using a Hewlett Packard G1800A GCD System chromatograph equipped with an electron ionization detector, an HP-5 (30 m $\times 0.25$ $\mathrm{mm} \times 0.25 \mu \mathrm{m})$ column and an HP 7673 automatic sampler, as described previously in detail (Torkko et al., 1998).

Biochemical methods. Tests for Tween 80 hydrolysis and semiquantitative catalase were performed as described previously (Vincent Lévy-Frébault \& Portaels, 1992; Torkko et al., 1998, 2000). Urease activity was determined using commercial discs (Rosco), following the manufacturer's recommendations but using overnight incubation at $36{ }^{\circ} \mathrm{C}$.
Table 1. Mycobacterial reference strains representing the species included in the study

\begin{tabular}{|c|c|}
\hline Species & Strain \\
\hline Mycobacterium asiaticum & ATCC 25274 \\
\hline Mycobacterium asiaticum & ATCC $25276^{\mathrm{T}}$ \\
\hline Mycobacterium avium & ATCC 15769 \\
\hline Mycobacterium bohemicum & DSM $44277^{\mathrm{T}}$ \\
\hline Mycobacterium botniense & ATCC $700701^{\mathrm{T}}$ \\
\hline Mycobacterium branderi & ATCC $51789^{\mathrm{T}}$ \\
\hline Mycobacterium celatum type 1 & ATCC $51131^{\mathrm{T}}$ \\
\hline Mycobacterium celatum type 2 & ATCC 51130 \\
\hline Mycobacterium celatum type 3 & NCTC 12882 \\
\hline Mycobacterium conspicuum & DSM $44136^{\mathrm{T}}$ \\
\hline Mycobacterium cookii & ATCC $49103^{\mathrm{T}}$ \\
\hline Mycobacterium doricum & DSM $44339^{\mathrm{T}}$ \\
\hline Mycobacterium gastri & ATCC $15754^{\mathrm{T}}$ \\
\hline Mycobacterium genavense & ATCC $51234^{\mathrm{T}}$ \\
\hline Mycobacterium gordonae & ATCC $14470^{\mathrm{T}}$ \\
\hline Mycobacterium haemophilum & ATCC $29548^{\mathrm{T}}$ \\
\hline Mycobacterium heckeshornense & DSM $44428^{\mathrm{T}}$ \\
\hline Mycobacterium heidelbergense & ATCC $51253^{\mathrm{T}}$ \\
\hline Mycobacterium hiberniae & ATCC $49874^{\mathrm{T}}$ \\
\hline Mycobacterium interjectum & ATCC $51457^{\mathrm{T}}$ \\
\hline Mycobacterium intermedium & ATCC $51848^{\mathrm{T}}$ \\
\hline Mycobacterium intracellulare & ATCC $13950^{\mathrm{T}}$ \\
\hline Mycobacterium kansasii & ATCC $12478^{\mathrm{T}}$ \\
\hline Mycobacterium kubicae & CIP $106428^{\mathrm{T}}$ \\
\hline Mycobacterium lentiflavum & ATCC $51985^{\mathrm{T}}$ \\
\hline Mycobacterium malmoense & ATCC $29571^{\mathrm{T}}$ \\
\hline Mycobacterium marinum & ATCC $927^{\mathrm{T}}$ \\
\hline Mycobacterium nonchromogenicum & ATCC $19530^{\mathrm{T}}$ \\
\hline Mycobacterium palustre & DSM $44572^{\mathrm{T}}$ \\
\hline Mycobacterium scrofulaceum & ATCC $19981^{\mathrm{T}}$ \\
\hline Mycobacterium shimoidei & $\operatorname{ATCC} 27962^{\mathrm{T}}$ \\
\hline Mycobacterium simiae & ATCC $25275^{\mathrm{T}}$ \\
\hline Mycobacterium szulgai & ATCC $35799^{\mathrm{T}}$ \\
\hline Mycobacterium terrae & ATCC $15755^{\mathrm{T}}$ \\
\hline Mycobacterium triplex & ATCC $700071^{\mathrm{T}}$ \\
\hline Mycobacterium triviale & ATCC $23292^{\mathrm{T}}$ \\
\hline Mycobacterium tusciae & DSM $44338^{\mathrm{T}}$ \\
\hline Mycobacterium xenopi & ATCC $19250^{\mathrm{T}}$ \\
\hline
\end{tabular}

\section{RESULTS AND DISCUSSION}

The cellular fatty acids present in all of the mycobacterial species examined were hexadecanoic $(16: 0)$, tetradecanoic (14:0), hexadecenoic $(16: 1)$, octadecanoic $(18: 0)$ and octadecenoic (18:1) acids, as determined previously by Luquin et al. (1991). MACPs ranging from eicosanoic acid $(20: 0)$ to hexacosanoic acid $(26: 0)$ were detected in varying combinations and secondary alcohols and methyl-branched fatty acids were recovered in some of the species. On the basis of fatty acid, MACP and alcohol composition, the GLC profiles of slowly growing mycobacteria could be divided into six categories that formed the basis for our identification scheme. As shown in the key (Fig. 1), each main path was 


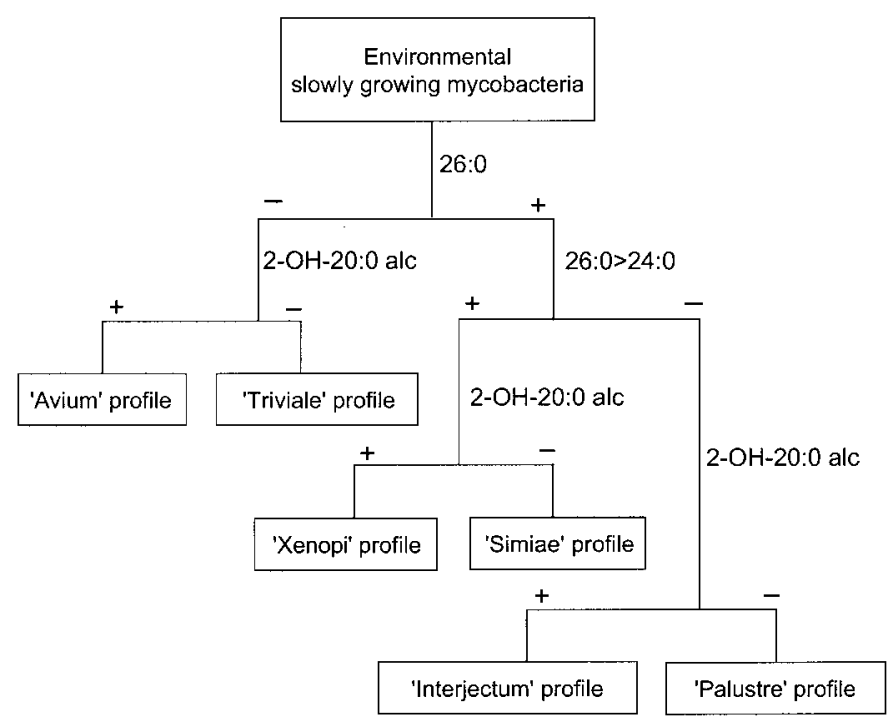

Fig. 1. A fatty acid/alcohol marker-based key for the identification of slowly growing environmental mycobacteria. characterized by a combination of fatty markers regarded as being typical for that category (Table 2). Each category included several species, some with and others without species-specific lipid markers. Whenever more than one species had an approximately similar basic profile without any distinguishing species-specific markers, one to three auxiliary tests were used to confirm the identification. Only tests that were quick to perform, gave reproducible results and had a high discriminatory power in the separation of the species with similar combinations of lipid content were used (Table 2).

\section{Category 'Avium'}

The category 'Avium' encompasses ten species: Mycobacterium avium, Mycobacterium bohemicum, M. cookii, Mycobacterium hiberniae, Mycobacterium intracellulare, $M y$ cobacterium nonchromogenicum, Mycobacterium scrofulaceum, Mycobacterium shimoidei, Mycobacterium terrae and Mycobacterium tusciae. The major MACP, tetracosanoic acid (24:0), is accompanied by two secondary alcohols, 2octadecanol (2-OH-18:0 alc) and 2-eicosanol (2-OH-20:0 alc) (Table 2; Fig. 2). Hexacosanoic acid (26:0) is not detected or it is present in only minute amounts. Some of the species in the 'Avium' category have specific lipid markers, allowing definite species identification (Table 2). The species lacking specific markers, $M$. avium complex, $M$. terrae, M. scrofulaceum, M. cookii and M. scrofulaceum, can be separated with the help of biochemical tests. For example, $M$. terrae is differentiated by a positive Tween 80 hydrolysis test result. In those isolates negative for Tween 80 hydrolysis, tests for urease and semi-quantitative catalase can separate $M$. avium complex from M. scrofulaceum and M. cookii (Table 2) but molecular probes are necessary for the separation of the two clinically important species among the $M$. avium complex, M. avium and M. intracellulare (Viljanen et al., 1993; Tortoli et al., 2001a). Our earlier results have highlighted a weakness in the use of AccuProbe for the M. avium complex (Gen-Probe). A novel species, Mycobacterium palustre, can hybridize with the M. avium complex AccuProbe (Torkko et al., 2002) and it could therefore be misidentified as $M$. avium complex if the identification is reliant on this probe test alone. However, in contrast to $M$. avium complex, $M$. palustre can hydrolyse Tween 80 . This simple test should always be applied in the verification of yellow isolates hybridizing with M. avium-complex AccuProbe. The GLC scheme applied easily separates M. palustre, which has a species-specific GLC profile (see Category 'Palustre'). The identification of $M$. scrofulaceum is confirmed by positive results in urease and semi-quantitative catalase tests. Rough colony morphology, intense yellow pigment and the inability to grow at $36^{\circ} \mathrm{C}$ can separate $M$. cookii from M. scrofulaceum and also from yellow-pigmented strains of $M$. avium complex.

\section{Category 'Triviale'}

The category 'Triviale' is composed of ten species, Mycobacterium asiaticum, Mycobacterium doricum, Mycobacterium gastri, Mycobacterium gordonae, M. haemophilum, Mycobacterium kansasii, Mycobacterium kubicae, M. marinum, $M y$ cobacterium szulgai and Mycobacterium triviale. In the basic profile represented by $M$. triviale, the main MACP is 24:0 and no secondary alcohols are present. Species other than $M$. triviale contain combinations of species-specific markers that enable their correct identification (Table 2). M. asiaticum was placed in the 'Triviale' category on the basis of the GLC profile of the type strain (ATCC $25276^{\mathrm{T}}$ ). In a visual inspection, the GLC profile of another reference strain of M. asiaticum appeared to be identical. Unexpectedly, GLCMS analysis indicated that the two peaks following 18:0 (Fig. 3 ) were not identical in the two strains. They were 2 methyloctadecanoic (2-Me-18:0) and nonadecanoic acid $(19: 0)$ in the $M$. asiaticum type strain (ATCC $25276^{\mathrm{T}}$ ), compared with tuberculostearic acid (10-Me-18:0) and 2$\mathrm{OH}-20: 0$ alc in $M$. asiaticum ATCC 25274. The amounts of both 19:0 and 2-OH-20:0 alc were small. In 16S rDNA sequencing, $M$. asiaticum ATCC 25274 had a one base 
Table 2. Fatty acid and MACP markers, pigment production and selected biochemical tests as a basis for species identification of slowly growing environmental Mycobacterium species, with special emphasis on recently classified species

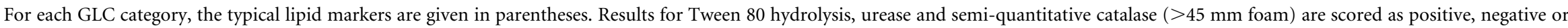
variable (v).

\begin{tabular}{|c|c|c|c|c|c|c|}
\hline Species & Species-specific markers ${ }^{\star}$ & Pigment $\dagger$ & Tween & Urease & Catalase & Reference(s) describing the profile \\
\hline \multicolumn{7}{|c|}{ Category 'Avium' (24:0, 2-OH-18:0 alc, 2-OH-20:0 alc) } \\
\hline M. avium & None & Nonet & - & - & - & $\begin{array}{l}\text { Chou et al. (1996), Garcia-Barceló et al. (1993), } \\
\text { Jantzen et al. (1989), Larsson et al. (1985), } \\
\text { Luquin et al. (1991) }\end{array}$ \\
\hline M. bohemicum & $\begin{array}{l}\text { 2-Me-20:0, 2,4-diMe-22:0, 2,4,6-triMe-22:0, } \\
\quad \text { 2,4,6-triMe-24:0 }\end{array}$ & Yellow ${ }^{\text {sc }}$ & $\mathrm{v}$ & + & + & Torkko et al. (2001) \\
\hline M. cookii & None & Yellow $^{\text {sc }}$ & - & - & + & This study (Fig. 2) \\
\hline M. hiberniae & $(8,15$-diMe-22: 1 alc), 8,17-diMe-24:1 alc & $\operatorname{Red}^{\mathrm{sc}}$ & - & - & + & This study (Fig. 2) \\
\hline M. intracellulare & None & None & - & - & - & Chou et al. (1996), Luquin et al. (1991) \\
\hline M. nonchromogenicum & 8,15-diMe-22: 1 alc, 8,17-diMe-24: 1 alc & None & + & - & + & Torkko et al. (1998) \\
\hline M. scrofulaceum & None & Yellow $^{\text {sc }}$ & - & + & + & This study (Fig. 2) \\
\hline M. shimoidei & 2-OH-22:0 alc & None & + & - & - & Koukila-Kähkölä et al. (2000) \\
\hline M. terrae & (8,17-diMe-24: 1 alc) & None & + & - & + & Torkko et al. (1998) \\
\hline M. tusciae & $22: 0>24: 0$ & Yellow ${ }^{\text {sc }}$ & + & + & - & This study (Fig. 2) \\
\hline \multicolumn{7}{|c|}{ Category 'Triviale' $(24: 0)$} \\
\hline M. asiaticum & $2-\mathrm{Me}-18: 0 \S, 2,4-\mathrm{diMe}-20: 0$ & Yellow $^{\text {ph }}$ & + & - & + & This study (Fig. 3) \\
\hline M. doricum & 2-OH-18:0 alc, (2-OH-20:0 alc) & Yellow $^{\text {sc }}$ & - & + & - & This study (Fig. 3) \\
\hline M. gastri & 2,4-diMe-14:0 & None & + & + & - & Larsson (1983) \\
\hline M. gordonae & $2-\mathrm{Me}-14: 0$, lack of TBSA & Yellow $^{\text {sc }}$ & + & - & + & Luquin et al. (1991); Chou et al. (1996) \\
\hline M. haemophilum & $22: 0>24: 0$ & None & - & - & - & Portaels et al. (1993) \\
\hline M. kansasii & 2-Me-14:0, 2,4-diMe-14:0 & Yellow $^{\text {ph }}$ & + & + & + & $\begin{array}{l}\text { Chou et al. (1996), Garcia-Barceló et al. (1993), } \\
\text { Jantzen et al. (1989), Luquin et al. (1991) }\end{array}$ \\
\hline M. kubicae & $2-\mathrm{Me}-14: 0$ & Yellow $^{\text {sc }}$ & + & - & + & This study (Fig. 3) \\
\hline M. marinum & $10-\mathrm{Me}-16: 0,2,4-\mathrm{diMe}-16: 0,(26: 0)$ & Yellow $^{\text {ph }}$ & + & + & - & $\begin{array}{l}\text { Chou et al. (1996), Jantzen et al. (1989), } \\
\text { Luquin } \text { et al. (1991) }\end{array}$ \\
\hline M. szulgai & $\begin{array}{l}\text { 2-Me-14:0, 10-Me-16:0, 2,4-diMe-20:0, } \\
\quad \text { 2,4,6-triMe-22:0 }\end{array}$ & Yellow $^{\mathrm{ph}, \mathrm{sc}} \|$ & + & + & + & $\begin{array}{l}\text { Chou et al. (1996), Luquin et al. (1991), } \\
\text { Müller et al. (1998) }\end{array}$ \\
\hline M. triviale & None & None & + & $\mathrm{v}$ & + & Luquin et al. (1993) \\
\hline \multicolumn{7}{|c|}{ Category 'Xenopi' (26:0>24:0, 2-OH-20:0 alc) } \\
\hline M. botniense & $\begin{array}{l}\text { 2-OH-22:0 alc, } 2,4,6, x \text {-tetraMe-20:0, } \\
\text { 2,4,6,x,x,-pentaMe- } 22: 0\end{array}$ & Yellow ${ }^{\text {sc }}$ & - & - & - & This study (Fig. 4) \\
\hline
\end{tabular}




\begin{tabular}{|c|c|c|c|c|c|c|}
\hline M. branderi & None & None & - & - & - & This study (Fig. 4) \\
\hline M. celatum & None & Nonet & - & - & - & Butler et al. (1993) \\
\hline M. heckeshornense & $2-\mathrm{OH}-22: 0$ alc $>2-\mathrm{OH}-20: 0$ alc & Yellowsc & - & - & - & This study (Fig. 4) \\
\hline M. xenopi & $(12: 0), 2-\mathrm{OH}-22: 0$ alc $>2-\mathrm{OH}-20: 0$ alc & Yellow ${ }^{\text {sc }}$ & - & - & - & $\begin{array}{l}\text { Alugupalli \& Larsson (1992), Butler et al. (1993), } \\
\text { Chou et al. (1996), Jantzen et al. (1989), } \\
\text { Larsson et al. (1989), Luquin et al. (1991) }\end{array}$ \\
\hline \multicolumn{7}{|c|}{ Category 'Simiae' $(26: 0>24: 0)$} \\
\hline M. genavense & None & None & - & + & + & Chou et al. (1998) \\
\hline M. heidelbergense & 2-Me-20:0, (2,4-diMe-22:0), 2,4,6-triMe-24:0 & None & + & + & - & This study (Fig. 5) \\
\hline M. lentiflavum & None & Yellow ${ }^{\text {sc }}$ & - & - & - & This study (Fig. 5) \\
\hline M. malmoense & 2-Me-20:0, (2,4-diMe-22:0), 2,4,6-triMe-24:0 & None & + & $\mathrm{V}$ & + & $\begin{array}{l}\text { Chou et al. (1996), Jantzen et al. (1989), } \\
\text { Luquin et al. (1991), Valero-Guillén et al. (1988) }\end{array}$ \\
\hline M. simiae & None & Yellow $^{\text {ph }}$ & - & + & + & Chou et al. (1998), Garcia-Barceló et al. (1993) \\
\hline M. triplex & None & None & - & + & + & This study (Fig. 5) \\
\hline \multicolumn{7}{|c|}{ Category 'Interjectum' (24:0, $26: 0,2-\mathrm{OH}-18: 0$ alc, $2-\mathrm{OH}-20: 0$ alc $)$} \\
\hline M. conspicuum & $2-\mathrm{Me}-12: 0,2-\mathrm{Me}-14: 0$ & None & + & - & - & This study (Fig. 6) \\
\hline M. interjectum & $\begin{array}{l}\text { 2-Me-10:0, 2-Me-20:0, 2,4-diMe-22:0, } \\
\text { 2,4,6-triMe-24:0 }\end{array}$ & Yellow ${ }^{\mathrm{sc}}$ & + & + & + & Torkko et al. (2002) \\
\hline \multicolumn{7}{|c|}{ Category 'Palustre' $(24: 0,26: 0)$} \\
\hline M. intermedium & $\begin{array}{l}\text { 12-Me-12:0, 2-Me-14:0, 2,4-diMe-20:0, } \\
\text { 2,4,6-triMe-22:0 }\end{array}$ & Yellow ${ }^{\mathrm{ph}}$ & + & $\mathrm{v}$ & + & Torkko et al. (2002) \\
\hline M. palustre & $\begin{array}{l}\text { 2-Me-10:0, 2-Me-19:0, 2-Me-20:0, } \\
\text { 2,9-diMe-20:0, 14-phe-14:0, 2-Me-16-phe-16:0 }\end{array}$ & Yellow $^{\text {sc,ph }}$ & + & + & - & Torkko et al. (2002) \\
\hline
\end{tabular}

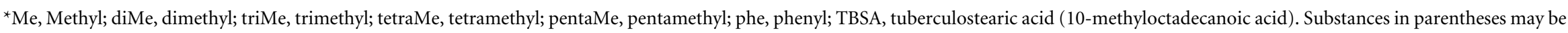
detected in minor amounts.

$\dagger \mathrm{sc}$, Scotochromogenic; ph, photochromogenic.

$\$$ Older cultures may develop yellowish pigment (Wayne et al., 1993; Butler et al., 1993).

§See text.

$\|$ Photochromogenic at $25^{\circ} \mathrm{C}$, scotochromogenic at $37^{\circ} \mathrm{C}$.

- Scotochromogenic at $36^{\circ} \mathrm{C}, 85 \%$ of isolates photochromogenic at $42{ }^{\circ} \mathrm{C}$. 

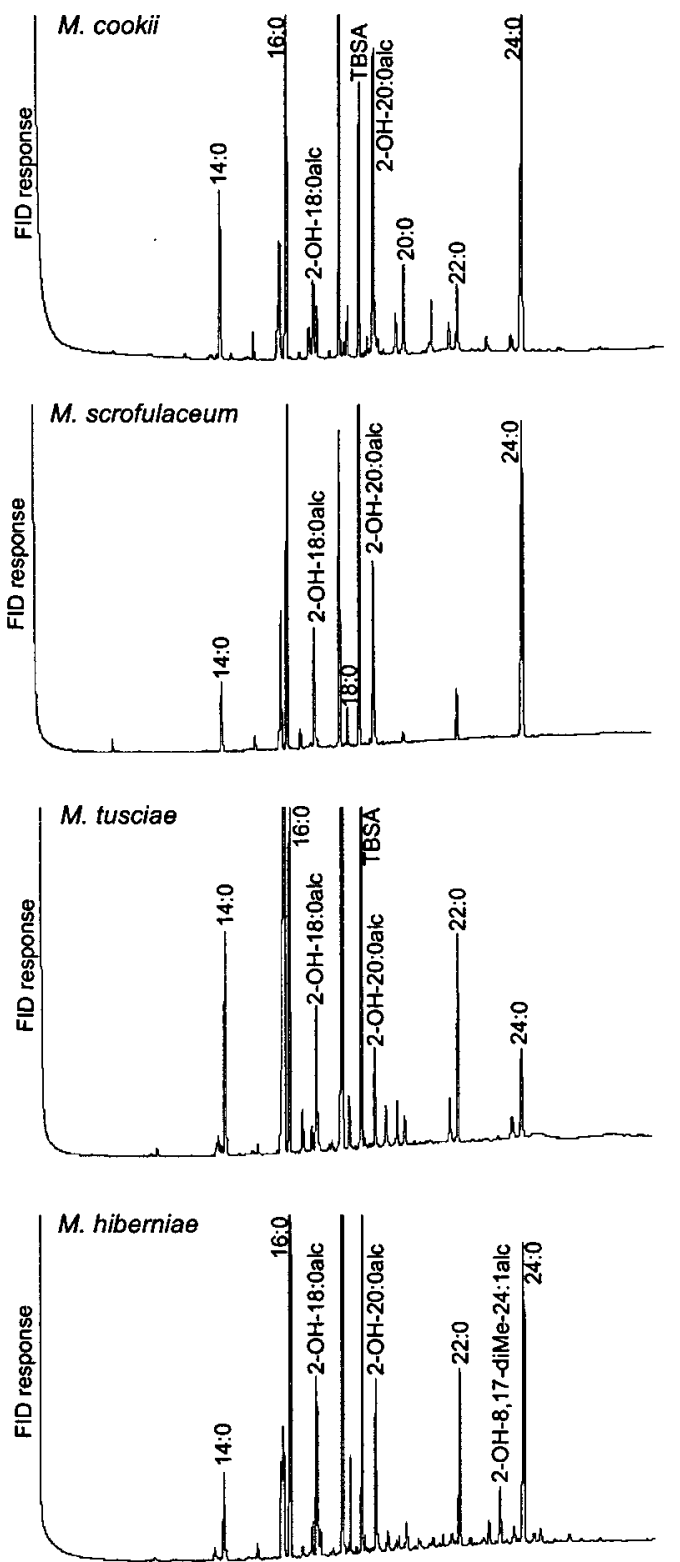

Fig. 2. GLC profiles of M. cookii, M. scrofulaceum, M. tusciae and $M$. hiberniae in the category 'Avium'. FID, Flame-ionization detector. See Table 2 for explanation of other abbreviations.

difference from the type strain (Turenne et al., 2001), at position 1020 of the $16 \mathrm{~S}$ rDNA. M. doricum, also included in this category, contains only trace amounts of 2-OH-20:0 alc (Tortoli et al., 2001b).

\section{Category 'Xenopi'}

The species placed in the category 'Xenopi' have a GLC pattern characterized by the presence of 2-OH-20:0 alc and a large amount of $26: 0(26: 0>24: 0)$. This category consists of M. botniense, Mycobacterium branderi, Mycobacterium celatum, $M$. heckeshornense and M. xenopi. The GLC profiles of $M$. branderi and M. celatum are characterized by their large
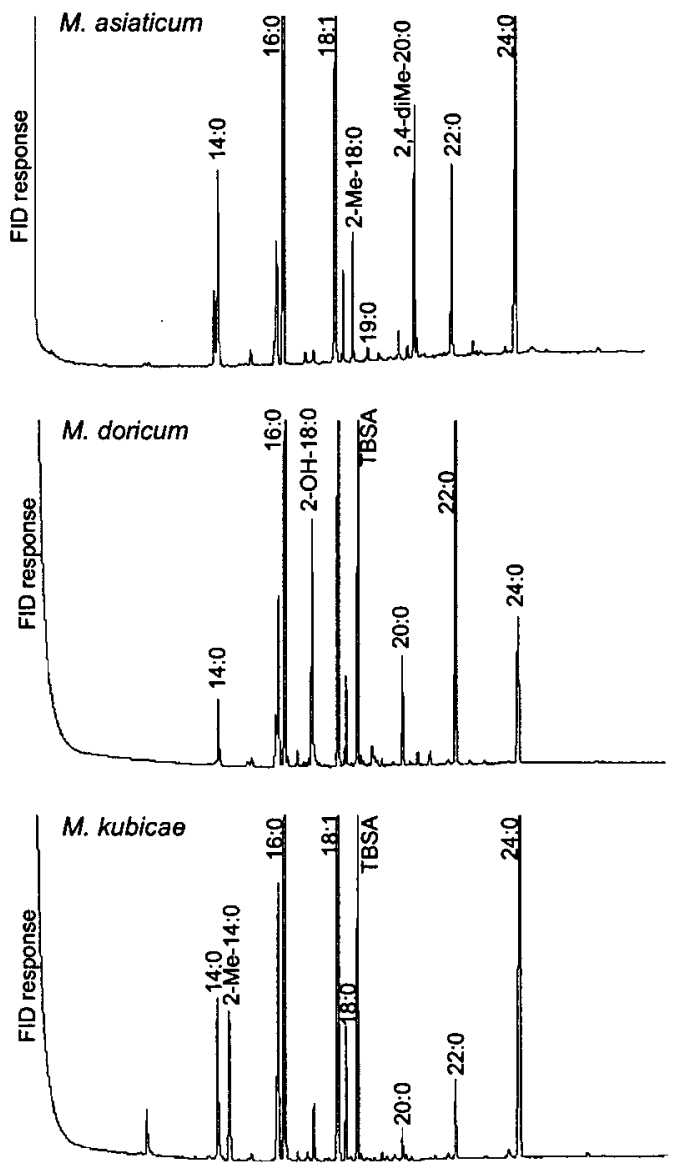

Fig. 3. GLC profiles of M. asiaticum, M. doricum and M. kubicae in the category 'Triviale'.

amounts of 2-OH-20:0 alc. In M. branderi, the amount of $26: 0$ is always greater than that of $24: 0$, whereas the three subtypes of M. celatum (types 1, 2 and 3) differ in their relative amounts of $24: 0$ and $26: 0$. Though $M$. branderi and M. celatum are indistinguishable by both GLC and biochemical tests (Koukila-Kähkölä et al., 1995), M. branderi is always non-pigmented whereas, in our experience, M. celatum always produces variable amounts of yellow pigment. A recent report has indicated that the tellurite tolerance test could be used to differentiate between these two species (Wolfe et al., 2000). The GLC profiles of M. botniense, M. heckeshornense and M. xenopi contain large amounts of 2docosanol (2-OH-22: 0 alc). Of these species, M. botniense is separated by the presence of two specific markers (Table 2; Fig. 4), one of which co-elutes with 2-OH-22:0 alc (Torkko et al., 2000). Differentiation of M. heckeshornense from $M$. xenopi is problematic (Roth et al., 2000, 2001; Richter et al., 2001) and, to our knowledge, reliable separation between the two can only be attained by $16 \mathrm{~S}$ rDNA sequencing at present.

\section{Category 'Simiae'}

The category 'Simiae' consists of M. genavense, Mycobacterium heidelbergense, Mycobacterium lentiflavum, Mycobacter- 

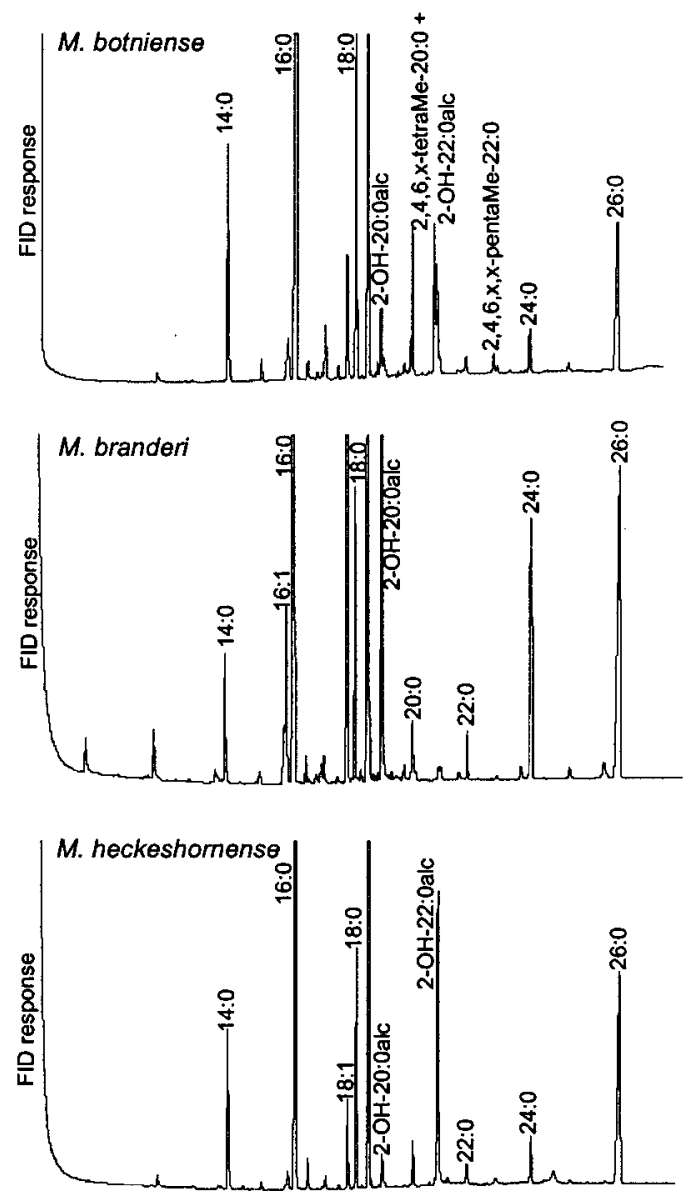

Fig. 4. GLC profiles of M. botniense, M. branderi and M. heckeshornense in the category 'Xenopi'.

ium malmoense, Mycobacterium simiae and Mycobacterium triplex. The major MACP is $26: 0$, and its amount is always greater than that of $24: 0$. The basic profile of this category is similar to that of Mycobacterium tuberculosis with the exception that the 14:0 peak is always substantial in this category, whereas it is a minor peak in M. tuberculosis. M. malmoense and $M$. heidelbergense have the same species-specific fatty markers. However, in the profile of $M$. malmoense, the amount of 2,4,6-trimethyltetracosanoic acid (2,4,6-triMe$24: 0)$ is always greater than that of $24: 0$. This ratio is opposite to the profiles of the two isolates of $M$. heidelbergense available for our analyses so far. However, more isolates of $M$. heidelbergense should be analysed to confirm this observation. Fastidious growth and the requirement for mycobactin $J$ separate $M$. genavense from the other species in this group (Böttger et al., 1993). Three species, M. lentiflavum, M. simiae and M. triplex, have highly similar profiles (Fig. 5) (Chou et al., 1998; Garcia-Barceló et al., 1993). M. triplex, with its variants (Suomalainen et al., 2001), does not produce pigment. The scotochromogenic M. lentiflavum is negative in most biochemical tests (Springer et al., 1996). It grows as pinpoint colonies, in contrast to the photochromogenic $M$. simiae, growth of which is more abundant. According to
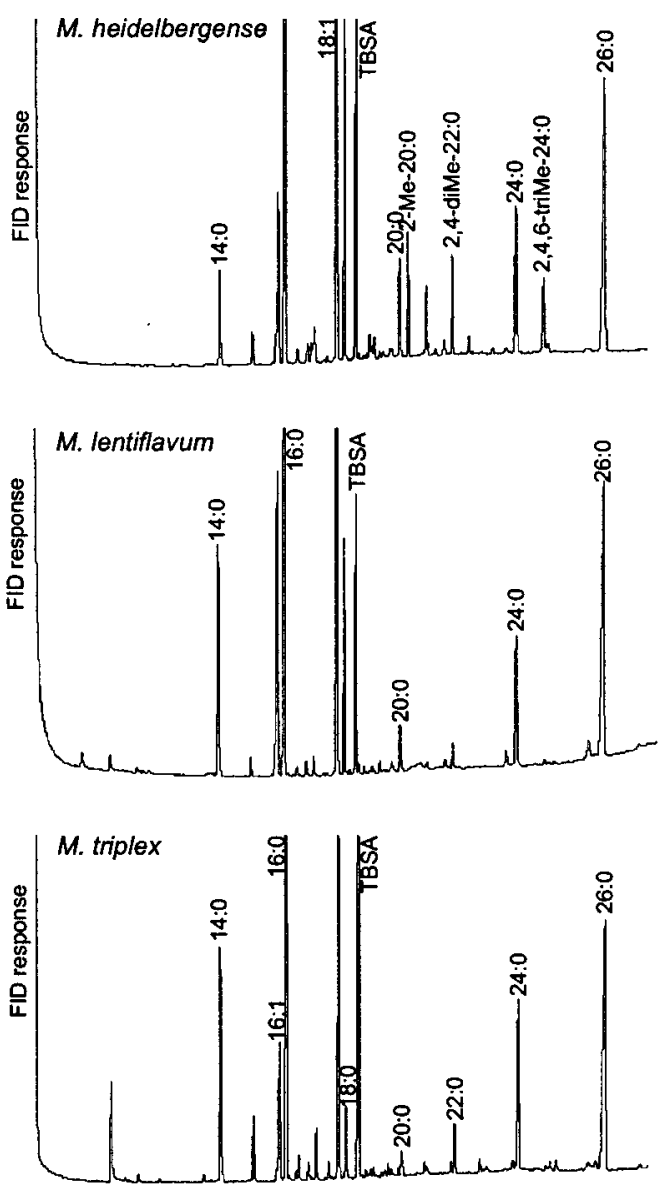

Fig. 5. GLC profiles of $M$. heidelbergense, $M$. lentiflavum and $M$. triplex in the category 'Simiae'.

Chou et al. (1998), M. simiae can be differentiated from $M$. genavense and $M$. tuberculosis by the presence of cis-11hexadecenoic acid (cis-11-16:1) and the lack of cis-10hexadecenoic acid (cis-10-16:1) in the GLC pattern.

\section{Categories 'Interjectum' and 'Palustre'}

The remaining two categories, 'Interjectum' and 'Palustre', are characterized by the presence of several methyl-branched fatty markers and both 24:0 and 26:0 as MACPs. The differentiating feature of the category 'Interjectum' is the presence of the secondary alcohols 2-OH-18:0 alc and 2$\mathrm{OH}-20: 0$ alc. Mycobacterium interjectum and Mycobacterium conspicuum differ in their specific fatty markers (Table 2; Fig. 6) and are therefore easily identifiable by GLC. In contrast, the category 'Palustre' lacks secondary alcohols. The two species in this category, M. palustre and Mycobacterium intermedium, have unique combinations of methylbranched fatty acids (Torkko et al., 2002).

\section{Conclusions}

GLC and HPLC are widely used in the routine identification of mycobacteria, in spite of the increasing number of genetic 


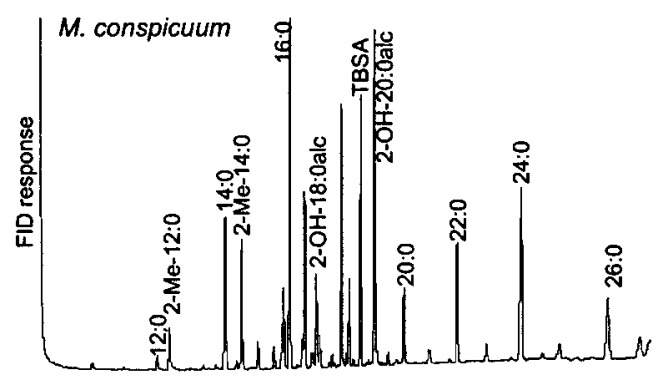

Fig. 6. GLC profile of M. conspicuum in the category 'Interjectum'.

methods designed for the identification of mycobacteria. In our experience, GLC is reliable and reproducible in the identification of both pathogenic and environmental slowly growing mycobacteria. In our identification scheme, we have added one to three biochemical tests to confirm the initial identification result.

The criteria for identification of a species should never be based on a single isolate, regardless of the method used. This also applies to GLC analysis. More than one isolate has to be analysed to ensure the significance of the marker substances that are being regarded as typical of this species. This principle has also been used as the basis of the scheme developed, though, for the present article, the GLC profiles of the type strains were selected. In this study, our major emphasis was placed on rare species whose fatty profiles have remained unavailable in the literature. Though the number of isolates of some species has remained small to date, more than one isolate has been included in our analyses.

Our experience has also verified the usefulness of GLC in the grouping of mycobacteria belonging to previously undescribed species (Koukila-Kähkölä et al., 1995; Torkko et al., 2000,2002 ). This grouping can be used as a basis for an extended identification scheme, which may eventually lead to the description of a novel species. In our research studies and in the routine identification of clinical and veterinary isolates, all but the most recent species have been represented. Nonetheless, among mycobacteria recovered from a variety of environmental sources (Iivanainen et al., 1993; Katila et al., 1995), the majority of isolates represent species other than those fully characterized today. This leads us to assume that species identification will become an even more complicated procedure in the future.

According to our current experience, no single identification technique alone, including sequencing of a single gene such as $16 \mathrm{~S}$ rRNA, allows infallible identification of all established mycobacterial species. Therefore, a rational battery of techniques should be available in all laboratories that perform mycobacterial identification.

\section{REFERENCES}

Alugupalli, S. \& Larsson, L. (1992). Secondary fatty alcohols of Mycobacterium xenopi. J Gen Microbiol 138, 2499-2502.
Böttger, E. C., Hirschel, B. \& Coyle, M. B. (1993). Mycobacterium genavense sp. nov. Int J Syst Bacteriol 43, 841-843.

Brander, E., Jantzen, E., Huttunen, R., Julkunen, A. \& Katila, M.-L. (1992). Characterization of a distinct group of slowly growing mycobacteria by biochemical tests and lipid analyses. J Clin Microbiol 30, 1972-1975.

Butler, W. R. \& Guthertz, L. S. (2001). Mycolic acid analysis by highperformance liquid chromatography for identification of Mycobacterium species. Clin Microbiol Rev 14, 704-726.

Butler, W. R., O'Connor, S. P., Yakrus, M. A. \& 8 other authors (1993). Mycobacterium celatum sp. nov. Int J Syst Bacteriol 43, 539-548.

Carbonara, S., Tortoli, E., Costa, D. \& 7 other authors (2000). Disseminated Mycobacterium terrae infection in a patient with advanced human immunodeficiency virus disease. Clin Infect Dis 30, 831-835.

Chou, S., Chedore, P., Haddad, A., Paul, N. R. \& Kasatiya, S. (1996). Direct identification of Mycobacterium species in Bactec 7H12B medium by gas-liquid chromatography. J Clin Microbiol 34, 1317-1320.

Chou, S., Chedore, P. \& Kasatiya, S. (1998). Use of gas chromatographic fatty acid and mycolic acid cleavage product determination to differentiate among Mycobacterium genavense, Mycobacterium fortuitum, Mycobacterium simiae, and Mycobacterium tuberculosis. J Clin Microbiol 36, 577-579.

Garcia-Barceló, M., Luquin, M., Belda, F. \& Ausina, V. (1993). Gas chromatographic whole-cell fatty acid analysis as an aid for the identification of mixed mycobacterial cultures. J Chromatogr 617, 299-303.

livanainen, E. K., Martikainen, P. J., Väänänen, P. K. \& Katila, M.-L. (1993). Environmental factors affecting the occurrence of mycobacteria in brook waters. Appl Environ Microbiol 59, 398-404.

Jantzen, E., Tangen, T. \& Eng, J. (1989). Gas chromatography of mycobacterial fatty acids and alcohols: diagnostic applications. APMIS 97, 1037-1045.

Katila, M.-L., livanainen, E., Torkko, P., Kauppinen, J., Martikainen, P. \& Väänänen, P. (1995). Isolation of potentially pathogenic mycobacteria in the Finnish environment. Scand J Infect Dis Suppl 98, 9-11.

Koukila-Kähkölä, P., Springer, B., Böttger, E. C., Paulin, L., Jantzen, E. \& Katila, M.-L. (1995). Mycobacterium branderi sp. nov., a new potential human pathogen. Int J Syst Bacteriol 45, 549-553.

Koukila-Kähkölä, P., Paulin, L., Brander, E., Jantzen, E., Eho-Remes, M. \& Katila, M.-L. (2000). Characterisation of a new isolate of Mycobacterium shimoidei from Finland. J Med Microbiol 49, 937-940.

Larsson, L. (1983). Acidic methanolysis v. alkaline saponification in gas chromatographic characterization of mycobacteria: differentiation between Mycobacterium avium-intracellulare and Mycobacterium gastri. Acta Pathol Microbiol Immunol Scand Sect B 91, 235-239.

Larsson, L., Jantzen, E. \& Johnsson, J. (1985). Gas chromatographic fatty acid profiles for characterisation of mycobacteria: an interlaboratory methodological evaluation. Eur J Clin Microbiol 4, 483-487.

Larsson, L., Jiménez, J., Valero-Guillén, P., Martín-Luengo, F. \& Kubín, M. (1989). Establishment of 2-docosanol as a cellular marker compound in the identification of Mycobacterium xenopi. J Clin Microbiol 27, 2388-2390.

Luque, A. E., Kaminski, D., Reichman, R. \& Hardy, D. (1998). Mycobacterium szulgai osteomyelitis in an AIDS patient. Scand J Infect Dis 30, 88-91.

Luquin, M., Ausina, V., López Calahorra, F., Belda, F., García Barceló, M., Celma, C. \& Prats, G. (1991). Evaluation of practical chromatographic procedures for identification of clinical isolates of mycobacteria. J Clin Microbiol 29, 120-130.

Luquin, M., Ausina, V., Vincent-Lévy-Frébault, V., Lanéelle, M. A., 
Belda, F., García-Barceló, M., Prats, G. \& Daffé, M. (1993). Mycobacterium brumae sp. nov., a rapidly growing, nonphotochromogenic mycobacterium. Int J Syst Bacteriol 43, 405-413.

Mayo, J., Collazos, J. \& Martínez, E. (1998). Mycobacterium nonchromogenicum bacteremia in an AIDS patient. Emerg Infect Dis 4, 124-125.

Müller, K.-D., Schmid, E. N. \& Kroppenstedt, R. M. (1998). Improved identification of mycobacteria by using the Microbial Identification System in combination with additional trimethylsulfonium hydroxide pyrolysis. J Clin Microbiol 36, 2477-2480.

Portaels, F., Dawson, D. J., Larsson, L. \& Rigouts, L. (1993). Biochemical properties and fatty acid composition of Mycobacterium haemophilum: study of 16 isolates from Australian patients. J Clin Microbiol 31, 26-30.

Richter, E., Niemann, S., Ruesch-Gerdes, S. \& Harmsen, D. (2001). Description of Mycobacterium heckeshornense sp. nov. J Clin Microbiol 39, 3023 .

Roth, A., Reischl, U., Schönfeld, N., Naumann, L., Emler, S., Fischer, M., Mauch, H., Loddenkemper, R. \& Kroppenstedt, R. M. (2000). Mycobacterium heckeshornense sp. nov., a new pathogenic slowly growing Mycobacterium sp. causing cavitary lung disease in an immunocompetent patient. J Clin Microbiol 38, 4102-4107.

Roth, A., Mauch, H., Schönfeld, N., Loddenkemper, R., Reischl, U., Naumann, L. \& Kroppenstedt, R. M. (2001). Description of Mycobacterium heckeshornense sp. nov - Authors' reply. J Clin Microbiol 39, 3023-3024.

Springer, B., Wu, W.-K., Bodmer, T. \& 10 other authors (1996). Isolation and characterization of a unique group of slowly growing mycobacteria: description of Mycobacterium lentiflavum sp. nov. J Clin Microbiol 34, 1100-1107.

Suomalainen, S., Koukila-Kähkölä, P., Brander, E., Katila, M.-L., Piilonen, A., Paulin, L. \& Mattson, K. (2001). Pulmonary infection caused by an unusual, slowly growing nontuberculous mycobacterium. J Clin Microbiol 39, 2668-2671.

Torkko, P., Suutari, M., Suomalainen, S., Paulin, L., Larsson, L. \& Katila, M.-L. (1998). Separation among species of Mycobacterium terrae complex by lipid analyses: comparison with biochemical tests and $16 \mathrm{~S}$ rRNA sequencing. J Clin Microbiol 36, 499-505.

Torkko, P., Suomalainen, S., livanainen, E., Suutari, M., Tortoli, E., Paulin, L. \& Katila, M.-L. (2000). Mycobacterium xenopi and related organisms isolated from stream waters in Finland and description of Mycobacterium botniense sp. nov. Int J Syst Evol Microbiol 50, 283-289.

Torkko, P., Suomalainen, S., livanainen, E. \& 7 other authors (2001). Characterization of Mycobacterium bohemicum isolated from human, veterinary, and environmental sources. J Clin Microbiol 39, 207-211.
Torkko, P., Suomalainen, S., livanainen, E., Tortoli, E., Suutari, M., Seppänen, J., Paulin, L. \& Katila, M.-L. (2002). Mycobacterium palustre sp. nov., a potentially pathogenic, slowly growing mycobacterium isolated from clinical and veterinary specimens and from Finnish stream waters. Int J Syst Evol Microbiol 52, 1519-1525.

Tortoli, E., Nanetti, A., Piersimoni, C. \& 11 other authors (2001a). Performance assessment of new multiplex probe assay for identification of mycobacteria. J Clin Microbiol 39, 1079-1084.

Tortoli, E., Piersimoni, C., Kroppenstedt, R. M., Montoya-Burgos, J. I., Reischl, U., Giacometti, A. \& Emler, S. (2001b). Mycobacterium doricum sp. nov. Int J Syst Evol Microbiol 51, 2007-2012.

Turenne, C. Y., Tschetter, L., Wolfe, J. \& Kabani, A. (2001). Necessity of quality-controlled $16 \mathrm{~S}$ rRNA gene sequence databases: identifying nontuberculous Mycobacterium species. J Clin Microbiol 39, 3637-3648.

Valero-Guillén, P., Martín-Luengo, F., Larsson, L., Jimenez, J., Juhlin, I. \& Portaels, F. (1988). Fatty and mycolic acids of Mycobacterium malmoense. J Clin Microbiol 26, 153-154.

Viljanen, M. K., Olkkonen, L. \& Katila, M.-L. (1993). Conventional identification characteristics, mycolate and fatty acid composition, and clinical significance of MAIX AccuProbe-positive isolates of Mycobacterium avium complex. J Clin Microbiol 31, 1376-1378.

Vincent Lévy-Frébault, V. \& Portaels, F. (1992). Proposed minimal standards for the genus Mycobacterium and for description of new slowly growing Mycobacterium species. Int J Syst Bacteriol 42, 315-323.

Wayne, L. G., Good, R. C., Tsang, A. \& 13 other authors (1993). Serovar determination and molecular taxonomic correlation in Mycobacterium avium, Mycobacterium intracellulare, and Mycobacterium scrofulaceum: a cooperative study of the International Working Group on Mycobacterial Taxonomy. Int J Syst Bacteriol 43, 482-489.

Willumsen, P., Karlson, U., Stackebrandt, E. \& Kroppenstedt, R. M. (2001). Mycobacterium frederiksbergense sp. nov., a novel polycyclic aromatic hydrocarbon-degrading Mycobacterium species. Int J Syst Evol Microbiol 51, 1715-1722.

Wilson, R. W., Steingrube, V. A., Böttger, E. C. \& 11 other authors (2001). Mycobacterium immunogenum sp. nov., a novel species related to Mycobacterium abscessus and associated with clinical disease, pseudooutbreaks and contaminated metalworking fluids: an international cooperative study on mycobacterial taxonomy. Int J Syst Evol Microbiol 51, 1751-1764.

Wolfe, J., Turenne, C., Alfa, M., Harding, G., Thibert, L. \& Kabani, A. (2000). Mycobacterium branderi from both a hand infection and a case of pulmonary disease. J Clin Microbiol 38, 3896-3899. 